\title{
Bio-Priming Benih Kedelai (Glycine Max (L.) Merrill) untuk Meningkatkan Mutu Perkecambahan
}

\author{
Soybean (Glycine Max (L.) Merrill) Seed Bio-priming to Enhance Germination Quality \\ Theresa Dwi Kurnia ${ }^{*}$, Endang Pudjihartati ${ }^{2}$, dan Livia Trihanni Hasan ${ }^{2}$ \\ ${ }^{1}$ Agroteknologi, Fakultas Pertanian dan Bisnis, UKSW, Jl. Diponegoro 52-60, Salatiga 50722, Indonesia \\ ${ }^{2}$ Fakultas Pertanian dan Bisnis, UKSW, Jl. Diponegoro 52-60, Salatiga 50722, Indonesia \\ Email:dwi.kurnia@staff.uksw.edu*Penulis untuk korespondensi
}

\begin{abstract}
High protein and fat as the character of soybean seeds cause soybean seeds to rapidly deteriorated and quality decrease. One way to improve the quality is by using priming or biopriming treatment. The aim of this study is to determine the effect of bio-priming to improve the germination quality. This research used yellow seed soybean var Grobogan that had been stored for three months, with experimental design using Random Group Design (RGD) and variances analysis with 5\% HSD test. The treatments were: 1) control (K), 2) Priming (M) in which soybean seed were primed into moist husk charcoal with a ratio of seed : husk charcoal : water $=3: 10: 3(w / w / v), 3)$ Bio-priming using EM-4 (E) which was conducted by soaking the seeds in a solution of EM-4 $0.3 \%$ for one hour, 4) Bio-priming using Trichoderma harzianum (T) by priming with $75 \mathrm{~g}$ of Trichoderma harzianum for a day and 5) Bio-priming using EM-4 + Trichoderma harzianum. The results showed that bio-priming using EM-4 improved viability, vigor and growth of soybean sprouts, while bio-priming using Trichoderma harzianum showed no significant differences in all the variables of observation compared to the control. Meanwhile bio-priming with a combination of EM-4 and Trichoderma harzianum tended to decrease the germination quality compared to the control.
\end{abstract}

Keywords: Soybean seed, bio-priming, EM-4, Trichoderma harzianum, germination

\section{Abstrak}

Sifat benih kedelai dengan kandungan protein dan lemak tinggi menjadi penyebab benih kedelai cepat mengalami deteriorasi atau penurunan mutu benih. Salah satu cara untuk meningkatkan mutu perkecambahan adalah dengan perlakuan pemeraman atau bio-priming. Tujuan penelitian ini adalah mengetahui pengaruh bio-priming dalam meningkatkan mutu perkecambahan. Penelitian ini menggunakan benih kedelai kuning varietas Grobogan yang sudah disimpan selama tiga bulan. Rancangan percobaan menggunakan Rancangan Acak Kelompok (RAK) dan data yang diperoleh dianalisis sidik ragam dengan uji Beda Nyata Jujur (BNJ) taraf signifikansi 5\%. Perlakuan dalam penelitian ini adalah: 1) Kontrol (K), 2) Priming (M) perlakuan matriks priming dengan memasukkan benih kedelai ke dalam media berupa arang sekam lembab dengan perbandingan benih : arang sekam : air $=3: 10: 3(\mathrm{~b} / \mathrm{b} / \mathrm{v}), 3)$ Biopriming menggunakan EM-4 (E) dengan cara merendam benih dalam larutan EM-4 0.3\% selama satu jam, 4) Bio-priming menggunakan Trichoderma harzianum (T) yaitu priming benih dengan 75 g Trichoderma harzianum selama satu hari, dan 5) Bio-priming menggunakan EM-4 + Trichoderma harzianum (ET). Hasil penelitian menunjukkan bahwa bio-priming dengan menggunakan EM-4 mampu memperbaiki viabilitas, vigor dan pertumbuhan kecambah kedelai, sedangkan bio-priming menggunakan Trichoderma harzianum tidak menunjukkan perbedaan nyata pada semua variabel pengamatan dibandingkan kontrol. Perlakuan biopriming menggunakan kombinasi EM-4 dan Trichoderma harzianum cenderung menurunkan mutu perkecambahan kedelai dibandingkan kontrol.

Kata kunci: Benih kedelai, Bio-priming, EM-4, Trichoderma harzianum, perkecambahan 


\section{Pendahuluan}

Benih kedelai merupakan benih yang tidak memiliki masa dormansi, kandungan protein dan lemaknya menyebabkan umur simpan benih sangat rendah. Benih kedelai varietas Grobogan memiliki kandungan protein tinggi yaitu $42,32 \%$ sedangkan kedelai impor hanya $37,84 \%$ (Nurrahman, 2015). Hal ini menyebabkan benih kedelai akan cepat mengalami deteriorasi atau penurunan mutu. Mutu benih yang rendah mengakibatkan rendahnya kualitas perkecambahan sehingga mempengaruhi nilai produksi. Sedangkan untuk memenuhi kebutuhan kedelai nasional yang meningkat setiap tahunnya diperlukan benih dengan mutu yang baik sehingga dapat menghasilkan tanaman dengan produktivitas yang tinggi (Sumarno dan Hartono, 1983). Salah satu cara untuk meningkatkan mutu benih kedelai yang sudah mengalami deteriorasi adalah dengan perlakuan pemeraman atau priming (Sadeghi dkk., 2011; Sucahyono dkk., 2013; Utami dkk., 2013). Priming adalah kegiatan hidrasi secara perlahan sebelum benih dikecambahkan, bertujuan agar potensi air benih mencapai keseimbangan untuk mengaktifkan kegiatan metabolisme dalam benih (Rouhi dkk., 2011).

Perlakuan priming dapat dikombinasikan dengan pemberian agen hayati yang mampu untuk meningkatkan kualitas perkecambahan benih, misalnya dengan mikroba pengikat nitrogen atau mikroba yang mampu menghasilkan hormon pertumbuhan atau mikroba untuk meningkatkan ketahanan terhadap cekaman. Perlakuan kombinasi ini dikenal dengan bio-priming. Salah satu mikroba yang dapat ditambahkan adalah Trichoderma harzianum, yaitu fungi yang dapat hidup di perakaran tanaman dan mampu meningkatkan panjang akar dan tinggi kecambah kedelai (Anitha dkk., 2015; Entesari dkk., 2013). Mikroba lain yang dapat ditambahkan adalah dengan EM-4, yaitu larutan yang berisi mikroba alami (Maspary, 2011). Diharapkan mikroorganisme yang terdapat dalam larutan EM-4 dapat meningkatkan mutu perkecambahan benih kedelai yang telah mengalami deteriorasi. Untuk itu melalui penelitian ini akan dilihat pengaruh pemberian EM-4, T. harzianum dan kombinasi keduanya dalam proses bio-priming terhadap mutu perkecambahan benih kedelai.

\section{Metode Penelitian}

Bahan utama yang digunakan dalam penelitian ini adalah benih kedelai kuning varietas Grobogan yang sudah mengalami masa simpan 3 bulan, kertas merang untuk uji perkecambahan secara Uji Kertas Digulung didirikan (UKDd), larutan EM-4 dan kultur $T$. harzianum. Dalam penelitian ini terdapat 5 perlakuan, yaitu: 1) kontrol (K) merupakan benih kedelai tanpa perlakuan, 2) priming (M) merupakan perlakuan matriks priming dengan memasukkan benih kedelai ke dalam media arang sekam lembab dengan perbandingan benih : arang sekam : air $=3: 10: 3(\mathrm{~b} / \mathrm{b} / \mathrm{v}), 3)$ biopriming dengan EM-4 (E) dilakukan dengan perendaman benih dalam larutan EM-4 0.3\% selama satu jam, 4) bio-priming dengan $T$. harzianum (T) yaitu priming benih dengan $75 \mathrm{~g}$ Trichoderma harzianum selama satu hari, dan 5) bio-priming dengan EM-4 + T. harzianum (ET) merupakan perlakuan perendaman benih dalam larutan EM-4 0,3\% selama satu jam, lalu dilanjutkan dengan pemberian $75 \mathrm{~g} \mathrm{~T}$. harzianum selama satu hari. Pengujian perkecambahan dilakukan dengan metode UKDd dan diulang sebanyak 5 kali. Rancangan percobaan menggunakan RAK dan data yang diperoleh dianalisis sidik ragam dengan uji BNJ taraf signifikansi 5\% yang akan dinyatakan hasilnya dengan pemberian kode huruf pada nilai pengamatan. Huruf yang sama menunjukkan tidak adanya perbedaan yang nyata, sedangkan huruf yang berbeda menunjukkan adanya perbedaan yang nyata pada hasil pengamatan. Pengamatan yang dilakukan dalam penelitian ini adalah:

- Daya berkecambah (DB)

$$
D B=\frac{(\Sigma K N 1+\Sigma K N 2)}{\Sigma \text { Benih ditanam }} \times \mathbf{1 0 0}
$$

- Kecepatan tumbuh (KCT)

$$
\mathrm{KCT}=\Sigma \frac{\mathrm{N}}{t 0}=\frac{\% \mathrm{KN} 1}{t 1}+\frac{\% \mathrm{KN} 2}{t 2}+\frac{\% \mathrm{KN} 3}{t 3}+\cdots+\frac{\% \mathrm{KN} \mathrm{y}}{t y}
$$

- Keserempakan tumbuh (KST)

$$
\text { KST }=\frac{\Sigma K N 1}{\Sigma \text { Benih ditanam }} \times 100
$$


Keterangan:

DB : Daya berkecambah (\%)

KCT : Kecepatan tumbuh (\%/etmal)

KST : Keserempakan tumbuh (\%)

$\sum$ KN 1 : Jumlah kecambah normal pengamatan pertama pada 5 hari setelah tanam (HST)

$\sum$ KN 2 : Jumlah kecambah normal akhir periode pengamatan (8 HST)

$\mathrm{N} \quad$ : Persentase kecambah normal setiap waktu pengamatan

$\% \mathrm{KN}$ : persentase kecambah normal setiap waktu pengamatan

$\mathrm{t}$ : waktu pengamatan (1x24 jam, $2 \times 24$ jam, $3 \times 24$ jam hingga y $x 24$ jam)

$\mathrm{t}_{\mathrm{y}} \quad:$ akhir periode pengamatan $(8 \times 24$ jam $)$

\section{Hasil dan Pembahasan}

\section{Viabilitas benih}

Kemampuan benih untuk berkecambah secara normal sangat dipengaruhi oleh mutu fisiologis benih. Mutu fisiologis akan mencapai nilai maksimal saat masak fisiologis dan akan mengalami penurunan atau deteriorasi selama masa penyimpanan. Dalam penelitian ini diamati viabilitas benih yang digambarkan melalui daya berkecambah, yaitu antara benih tanpa perlakuan priming (kontrol) dengan benih yang diberi perlakuan (Gambar 1).

Hasil pengujian menunjukkan daya berkecambah tertinggi ada pada perlakuan bio- priming dengan EM-4 (E) dan diikuti dengan perlakuan priming (M), sedangkan perlakuan bio-priming dengan T. Harzianum (T) tidak berbeda nyata dibandingkan kontrol dan perlakuan bio-priming dengan EM-4 $+T$. harzianum (ET) cenderung menurunkan daya berkecambah benih. Peningkatan daya berkecambah benih kedelai pada perlakuan $\mathrm{E}$ yaitu $72 \%$ dan $\mathrm{M}$ yaitu 55,2\% dibandingkan kontrol yang hanya 44,8\% menunjukkan adanya perbaikan seluler dalam benih selama proses priming (Arif dkk., 2010; Sucahyono., dkk. 2013). Selain itu pada perlakuan E dengan adanya mikroba yang mampu menghasilkan nutrisi selama proses priming akan memacu aktivitas sel di dalam benih sehingga dapat meningkatkan daya berkecambah benih kedelai. Pada perlakuan ET yaitu dengan pemberian Trichoderma harzianum setelah priming dengan EM-4 cenderung menurunkan daya berkecambah benih. Penurunan ini diduga karena Trichoderma harzianum menghasilkan alkohol. ContrerasCornejo dkk., (2009) menduga alkohol yang dihasilkan merupakan hasil perombakan dari nutrisi yang dihasilkan mikroba melalui perendaman dengan EM-4 sebelumnya. Alkohol yang dihasilkan oleh mikroba dapat merusak membran sel sehingga menimbulkan kebocoran sel benih kedelai dan mengakibatkan rendahnya daya berkecambah benih.

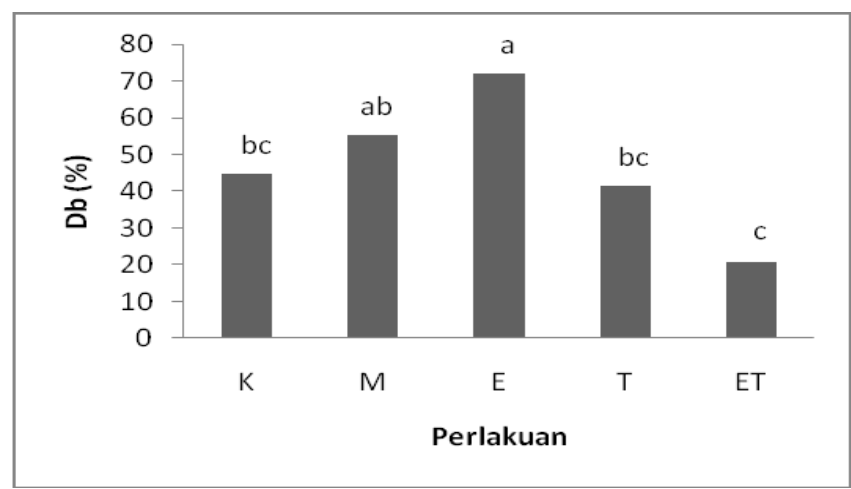

Gambar 1. Daya berkecambah benih kedelai.

Keterangan : $\mathrm{K}=$ Kontrol; $\mathrm{M}=$ Priming; $\mathrm{E}=$ Bio-priming dengan EM-4; $\mathrm{T}=$ Bio-priming dengan Trichoderma Harzianum; ET= Bio-priming dengan EM-4 + Trichoderma harzianum. Huruf yang sama di atas diagram menunjukkan tidak adanya perbedaan yang nyata, sedangkan huruf yang berbeda menunjukkan adanya perbedaan yang nyata. 


\section{Vigor benih}

Nilai vigor benih pada penelitian ini dilihat dari nilai kecepatan tumbuh (KCT) dan keserempakan tumbuh (KST) (Tabel 1). KCT menggambarkan persentase pertambahan kecambah normal per hari selama proses pengujian, sedangkan keserempakan tumbuh (KST) merupakan nilai yang menunjukkan persentase kecambah normal pada pengamatan $\mathrm{KNH}_{1}$ (kecambah normal hari pertama) yaitu hari ke-5. Apabila dibandingkan dengan benih kontrol $(\mathrm{K})$, perlakuan priming dengan matriks priming (M) dapat meningkatkan nilai $\mathrm{KCT}$ dan perlakuan bio-priming dengan EM-4 (E) menunjukkan nilai KCT tertinggi. Nilai KST benih kedelai dengan perlakuan $\mathrm{E}$ juga menunjukkan nilai tertinggi dibandingkan kontrol maupun perlakuan lain. Hal ini disebabkan waktu hidrasi dengan perlakuan E cukup panjang dan selama proses priming tersebut benih melakukan proses perbaikan seluler dengan memanfaatkan nutrisi yang dihasilkan oleh mikroba di dalam EM-4. Lamanya waktu priming juga berpengaruh pada proses metabolisme awal dari benih sebelum memasuki fase munculnya radikula (Yuanasari dkk., 2015). Proses inilah yang mendukung pembentukan kecambah normal pada perlakuan E lebih cepat dan lebih serempak dibandingkan perlakuan lain.

\section{Pertumbuhan kecambah}

Pertumbuhan kecambah yang diamati meliputi tinggi, panjang akar dan berat kering kecambah. Tinggi kecambah yang diamati meliputi tinggi epikotil dan hipokotil (Gambar 2). Benih kedelai dengan perlakuan $E$ menunjukkan kemampuan terbaik dibandingkan perlakuan yang lain, yaitu mengalami peningkatan vigor kecambah hingga pertumbuhan epikotil dan hipokotil tertinggi. Besarnya nilai tersebut juga didukung oleh nilai KCT dan KST. Benih dengan perlakuan E juga menunjukkan nilai KCT dan KST tertinggi dibandingkan perlakuan lain. Pada saat benih cepat berkecambah sehingga nilai KCT tinggi, maka benih tersebut akan tumbuh lebih dulu sehingga pada waktu pengamatan yang sama benih yang telah berkecambah tersebut akan lebih tinggi. Priming menggunakan EM-4 yang di dalamnya terkandung mikroba alami terbukti mampu meningkatkan kualitas perkecambahan karena mikroba di dalamnya mampu melarutkan ion fosfat dan menghasilkan asam amino, gula, serta hormon (Wididana, 2014). Menurut Ekosari dkk., (2011) kualitas perkecambahan yang baik ditunjukkan oleh kemampuan menghasilkan tinggi kecambah (epikotil dan hipokotil) serta akar yang lebih panjang.

Tabel 2 menunjukkan nilai tinggi kecambah yaitu penjumlahan epikotil dan hipokotil, panjang akar, dan berat kering kecambah. Pada pengamatan panjang akar tidak ada perbedaan yang nyata antar perlakuan, karena perlakuan priming tidak berpengaruh langsung terhadap pertumbuhan akar. Panjang akar akan lebih banyak dipengaruhi oleh ketersediaan air selama proses perkecambahan.

Bobot kering (BK) kecambah menggambarkan jumlah biomassa yang tersimpan di dalam kecambah kedelai. Pada umumnya biomassa tanaman terbentuk dari hasil fotosintesis, tetapi biomassa pada tahap perkecambahan akan lebih banyak dipengaruhi oleh kandungan cadangan makanan yang tersimpan di dalam benih. Benih yang sudah mengalami deteriorasi akan mengalami kerusakan atau kebocoran sel, hal ini dapat menyebabkan keluarnya cadangan makanan terlarut saat benih mengalami imbibisi. Perlakuan bio-priming bertujuan agar pada benih terjadi perbaikan seluler sehingga kebocoran benih dapat ditutupi. Diharapkan selama proses pemeraman tersebut terdapat interaksi yang menguntungkan antara benih dengan mikroba. Mikroba dapat memanfaatkan bahan bocoran sel untuk menghasilkan hormon-hormon tertentu yang mendukung perkecambahan benih (Zulueta-Rodríguez dkk., 2015). Nilai BK dapat menggambarkan energi perkecambahan, artinya pada benih dengan BK tinggi memiliki energi perkecambahan yang tinggi (Sadeghi dkk., 2011). Pada Tabel 2 terlihat adanya peningkatan BK kecambah antara kontrol dengan benih yang diberi perlakuan priming kecuali perlakuan ET, bahkan nilai BK pada perlakuan ET lebih rendah dibandingkan K. Hal ini karena waktu priming benih yang terlalu lama menyebabkan kerusakan sel yang lebih tinggi, sehingga kebocoran sel tersebut menyebabkan keluarnya cadangan makanan dari dalam benih yang berakibat menurunkan energi perkecambahan. 
Bio-Priming Benih Kedelai (Glycine Max (L.) Merrill)

Tabel 1. Nilai Kecepatan Tumbuh (KCT) dan Keserempakan Tumbuh (KST)

\begin{tabular}{ccccl}
\hline \hline Perlakuan & KCT (\%/ETMAL) & KST (\%) & \\
\hline \hline K & 37,7 & $\mathrm{~b}$ & 13,6 & $\mathrm{~b}$ \\
M & 40,8 & $\mathrm{ab}$ & 17,6 & $\mathrm{~b}$ \\
$\mathrm{E}$ & 62,4 & $\mathrm{a}$ & 35,2 & $\mathrm{a}$ \\
$\mathrm{T}$ & 48 & $\mathrm{~b}$ & 24,8 & $\mathrm{ab}$ \\
$\mathrm{ET}$ & 37,2 & $\mathrm{~b}$ & 10,4 & $\mathrm{~b}$ \\
\hline \hline
\end{tabular}

Keterangan: $\mathrm{K}=$ Kontrol; $\mathrm{M}=$ Priming; $\mathrm{E}=$ Bio-priming dengan EM-4; $\mathrm{T}=$ Bio-priming dengan Trichoderma Harzianum; ET= Bio-priming dengan EM-4 + Trichoderma harzianum. Huruf yang sama di samping nilai menunjukkan tidak adanya perbedaan yang nyata, sedangkan huruf yang berbeda menunjukkan adanya perbedaan yang nyata.

Tabel 2. Tinggi kecambah, panjang akar, dan berat kering kecambah normal

\begin{tabular}{ccccccc}
\hline \hline Perlakuan & \multicolumn{2}{c}{ Tinggi Kecambah $(\mathrm{cm})$} & \multicolumn{2}{c}{ Panjang Akar $(\mathrm{cm})$} & \multicolumn{2}{c}{ Berat Kering $(\mathrm{g})$} \\
\hline $\mathrm{K}$ & 16,9 & $\mathrm{ab}$ & 19,7 & $\mathrm{a}$ & 1,8 & $\mathrm{bc}$ \\
$\mathrm{M}$ & 18,5 & $\mathrm{ab}$ & 20,9 & $\mathrm{a}$ & 2,4 & $\mathrm{ab}$ \\
$\mathrm{E}$ & 22,3 & $\mathrm{a}$ & 22,5 & $\mathrm{a}$ & 3,2 & $\mathrm{a}$ \\
$\mathrm{T}$ & 20,2 & $\mathrm{ab}$ & 22,8 & $\mathrm{a}$ & 1,2 & $\mathrm{bc}$ \\
$\mathrm{ET}$ & 10,5 & $\mathrm{~b}$ & 13,8 & $\mathrm{a}$ & 0,9 & $\mathrm{c}$ \\
\hline \hline
\end{tabular}

Keterangan: $\mathrm{K}=$ Kontrol; $\mathrm{M}=$ Priming; $\mathrm{E}=$ Bio-priming dengan EM-4; $\mathrm{T}=$ Bio-priming dengan Trichoderma Harzianum; ET= Bio-priming dengan EM-4 + Trichoderma harzianum. Huruf yang sama di samping nilai menunjukkan tidak adanya perbedaan yang nyata, sedangkan huruf yang berbeda menunjukkan adanya perbedaan yang nyata.

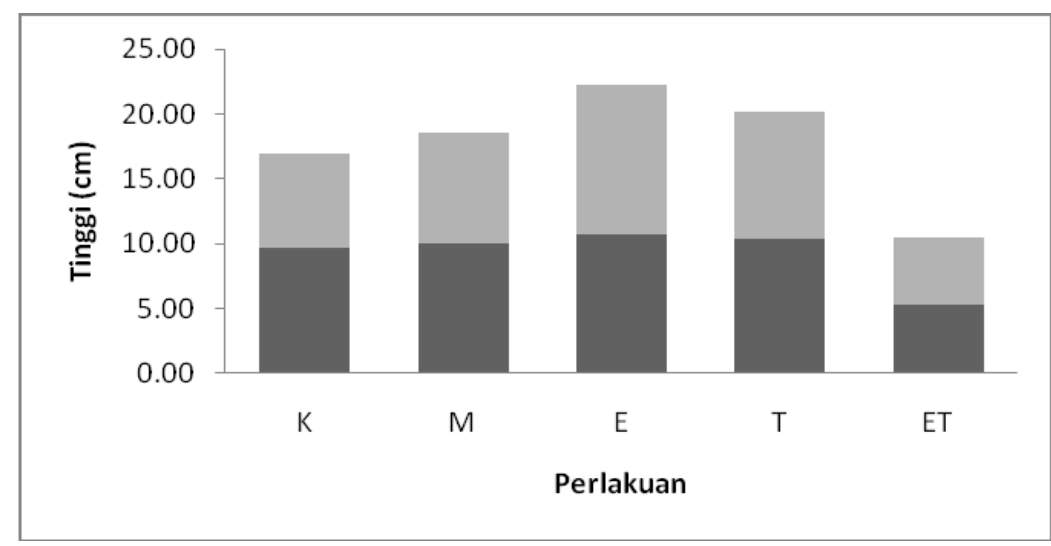

Gambar 2. Tinggi epikotil ( $\square$ ) dan hipokotil (

Keterangan : $\mathrm{K}=$ Kontrol; $\mathrm{M}=$ Priming; $\mathrm{E}=$ Bio-priming dengan EM-4; $\mathrm{T}=$ Bio-priming dengan Trichoderma Harzianum $; \mathrm{ET}=$ Biopriming dengan EM-4 + Trichoderma harzianum. Huruf yang sama di atas diagram menunjukkan tidak adanya perbedaan yang nyata, sedangkan huruf yang berbeda menunjukkan adanya perbedaan yang nyata. 


\section{Simpulan}

Berdasarkan hasil penelitian dapat disimpulkan bahwa bio-priming menggunakan EM-4 dapat memperbaiki mutu perkecambahan berdasarkan pengamatan viabilitas, vigor, dan pertumbuhan kecambah kedelai. Bio-priming menggunakan $T$. harzianum tidak mampu memperbaiki mutu perkecambahan benih kedelai dan bio-priming menggunakan kombinasi EM-4 dan $T$. harzianum cenderung menurunkan mutu perkecambahan kedelai dibandingkan kontrol.

\section{Ucapan Terima Kasih}

Penulis mengucapkan terima kasih kepada pimpinan Universitas Kristen Satya Wacana dan Dekan Fakultas Pertanian dan Bisnis yang telah memberikan dukungan selama penelitian hingga jurnal ini dapat diterbitkan. Terima kasih juga kepada mahasiswa yang telah terlibat dan membantu dalam pelaksanaan penelitian.

\section{Daftar Pustaka}

Anitha, Mummigatti, U.V. dan Shamarao, J. 2015. Influence of seed priming agents on yield, yield parameters and purple seed stain disease in soybean. Karnataka Journal Agric. Sci., 28 (1): 20-23.

Arif, M., Mohammad, T.J., Naqib, U.K.., Ahmad, K., Khan M.J. dan Iqbal, M. 2010. Effect of seed priming on growth parameters of soybean. Pak. Journal. Bot., 42 (4): 2803-2812.

Contreras-Cornejo, H.A., Mac1'as-Rodri'guez, L., Corte' sPenagos, C. dan Lo' pez-Bucio, J. 2009. Trichoderma virens, a plant beneficial fungus, enhances biomass production and promotes lateral root growth through an auxin-dependent mechanism in Arabidopsis. Plant Physiol., 149: 1579-1592.

Ekosari, R., Ariyanti, N.A. dan Widhy, P. 2011. Priming benih sebagai usaha peningkatan performansi bibit kubis (Brassica oleracea var. Capitata). Prosiding Seminar Nasional "Biology and Local Wisdom; Past, Present and Future". Biolog FMIPA, Universitas Negeri Yogyakarta. 2 Juli 2011
Entesari, M., Sharifzadeh, F., Ahmadzadeh, M. dan Farhangfar, M. 2013. Seed Biopriming with Trichoderma Species and Pseudomonas fluorescent on Growth Parameters, Enzymes Activity and Nutritional Status of Soybean. Int Journal Agron and Plant Prod., 4 (4): 610-619.

Maspary. 2011. Perbedaan EM4, Mol dan PGPR http://www.gerbangpertanian.com/2011/04/perbe daan-em4-mol-dan-pgpr.html. 15 April 2011. diakses pada 1 Juni 2015.

Nurrahman. 2015. Evaluasi komposisi zat gizi dan senyawa antioksidan kedelai hitam dan kedelai kuning. Journal Aplikasi Teknol. Pangan, 4 (3): 89-93.

Rouhi, H.R., Surki, A.A., Sharif-Zadeh, F., Afshari, R.T., Aboutalebian, M.A. dan Ahmadvand, G. 2011. Study of different priming treatments on germination traits of soybean seed lots. Notulae Sci Biol., 3 (1): 101-108.

Sadeghi, H., Fardin, K., Liela, Y. dan Saman, S. 2011. Effect of seed osmopriming on seed germination behavior and vigor of soybean (Glycine Max L.). Journal Agric and Biol Sci., 6 (1): 39-43.

Sucahyono, D., Sari, M., Surahman, M. dan Ilyas, S. 2013. Pengaruh perlakuan invigorasi pada benih kedelai hitam (Glycine soja) terhadap vigor benih, pertumbuhan tanaman dan hasil. Jurnal Agron Indonesia, 41 (2): 126-132.

Sumarno dan Hartono. 1983. Kedelai dan Cara Bercocok Tanamnya. Bogor: Pusat Penelitian dan Pengembangan Tanaman Pangan.

Utami, E.P., Maryati, S. dan Eny, W. 2013. Perlakuan priming benih untuk mempertahankan vigor benih kacang panjang (Vigna unguiculata) selama penyimpanan. Bul. Agrohorti, 1 (4): 75-82.

Wididana, G.N. 2014. Teknologi EM (Effective Microorganisms) Dimensi Baru dalam Pertanian Modern. http://em4-indonesia.com/teknologi-emeffective-microorganisms-demensi-baru-dalampertanian-modern/. Diakses 26 Mei 2016.

Yuanasari, B.S., Kendarini, N. dan Saptadi, D. 2015. Peningkatan viabilitas benih kedelai hitam (Glycine $\max$ 1. Merr) melalui invigorasi osmoconditioning. Jurnal Prod Tanaman. 3 (6): 518-527.

Zulueta-Rodríguez, R., Luis, G., Hernández, M., MurilloAmador, B., Rueda-Puente, E.O., Capistrán, L.L., Troyo-Diéguez, E. dan Córdoba-Matson, M.V. 2015. Effect of hydropriming and biopriming on seed germination and growth of two mexican fir tree species in danger of extinction. Forests Journal, 6: 3109-3122. 